\title{
Zrównoważone systemy żywnościowe w kontekście reformy Wspólnej Polityki Rolnej - aspekty prawne
}

1. Wyrażenie „zrównoważone systemy żywnościowe” nie należy do katalogu języka prawnego. Występuje ono w dokumentach o różnym charakterze i nie jest nowe ${ }^{1}$. Rozmaicie też tłumaczy się jego znaczenie. W dokumentach Unii Europejskiej od lat jest mowa o stworzeniu zrównoważonego, zdrowego, sprawiedliwego i przyjaznego dla klimatu systemu żywnościowego. Konieczne jest jednak zapewnienie większej spójności oraz integracji celów i instrumentów polityki żywnościowej (dotyczących np. rolnictwa, środowiska, zdrowia, klimatu, zatrudnienia) dzięki trzem filarom zrównoważenia². Z kolei według ekspertów wysokiego szczebla ds. bezpieczeństwa żywnościowego i żywienia Komitetu ds. Światowego Bezpieczeństwa Żywnościowego zrównoważony system żywnościowy definiuje sie jako „system żywnościowy, który zapewnia bezpieczeństwo żywnościowe i żywienie dla wszystkich w sposób niezagrażający gospodarczym, społecznym i środowiskowym podstawom bezpieczeństwa żywnościowego i żywienia dla

* Uniwersytet im. Adama Mickiewicza w Poznaniu.

${ }^{1}$ Opinia Europejskiego Komitetu Ekonomiczno-Społecznego w sprawie bardziej zrównoważonych systemów żywnościowych (opinia rozpoznawcza), 2016/C 303/08 (Dz. Urz. UE C 303/64 z 19.08.2016); Opinia Europejskiego Komitetu Ekonomiczno-Społecznego „Wkład społeczeństwa obywatelskiego w rozwój kompleksowej polityki żywnościowej w UE” (opinia z inicjatywy własnej), 2018/C 129/04 (Dz. Urz. UE C 129/18 z 11.04.2018).

${ }^{2}$ Opinia Europejskiego Komitetu Ekonomiczno-Społecznego w sprawie bardziej zrównoważonych systemów żywnościowych (opinia rozpoznawcza), 2016/C 303/08 (Dz. Urz. UE C 303/64 z 19.08.2016). 
przyszłych pokoleń"3. W maju $2020 \mathrm{r}$. na szczeblu unijnym przyjęta została strategia „Od pola do stołu” na rzecz sprawiedliwego, zdrowego i przyjaznego dla środowiska systemu żywnościowego ${ }^{4}$.

Zrównoważone systemy żywnościowe w UE łączą się z realizacją celów zrównoważonego rozwoju w płaszczyźnie międzynarodowej. Według Agendy na rzecz zrównoważonego rozwoju Organizacji Narodów Zjednoczonych $(\mathrm{ONZ})^{5}$ budowa zrównoważonych systemów żywnościowych powinna służyć takim celom, jak: wyeliminowanie głodu, osiągnięcie bezpieczeństwa żywnościowego i lepszego odżywiania oraz zrównoważenie rolnictwa. W świetle uregulowań krajowych budowanie zrównoważonych systemów żywnościowych odpowiada zasadzie zrównoważonego rozwoju ujętej w art. 5 Konstytucji Rzeczypospolitej Polskiej ${ }^{6}$.

Tematyka zrównoważonych systemów żywnościowych w kontekście reformy Wspólnej Polityki Rolnej (WPR) nie doczekała się dotąd opracowania monograficznego. Była natomiast poruszana na marginesie innych zagadnień, np. celów zrównoważonego rozwoju ${ }^{7}$ czy produktów żywnościowych ${ }^{8}$ i innych ${ }^{9}$. Zrównoważone systemy żywnościowe wiąże się w szczególności z bezpieczeństwem żywnościowym, w tym suwerennością żywnościową i zrównoważonym rozwojem żywnościowym odnoszonym do różnych aspek-

${ }^{3}$ HLPE, Food losses and waste in the context of sustainable food systems, Roma 2014.

${ }^{4}$ Komunikat Komisji do Parlamentu Europejskiego, Rady, Europejskiego Komitetu Ekonomiczno-Społecznego i Komitetu Regionów, Strategia „Od pola do stołu” na rzecz sprawiedliwego, zdrowego i przyjaznego dla środowiska systemu żywnościowego, COM/2020/381 final https:// www.europarl.europa.eu/news/pl/headlines/society/20200519STO79425/stworzenie-zrownowazonego-systemu-zywnosciowego-strategia-ue [dostęp: 15.09.2020].

${ }^{5}$ Rezolucja przyjęta przez Zgromadzenie Ogólne w dniu 25 września 2015 r. [bez odniesienia do Komitetu Głównego (A/70/L.1)] 70/1, Przekształcamy nasz świat: Agenda na rzecz zrównoważonego rozwoju 2030, http://www.unic.un.org.pl/files/164/Agenda\%202030_pl_2016_ostateczna. pdf [dostęp: 29.08.2020].

${ }^{6}$ Ustawa z 2 kwietnia 1997 r. (Dz. U. nr 78, poz. 483).

7 T. Srogosz, Systemy żywnościowe w kontekście Zrównoważonych Celów Rozwoju - kilka uwag w czasie pandemii, „Przegląd Prawa Publicznego” 2020, nr 6, s. 24-37.

${ }^{8}$ M. Żuchowska-Grzywacz, Zrównoważony produkt żywnościowy w systemie prawa - fakt czy życzenie?, „Problemy Jakości” 2018, nr 12, s. 7-12.

9 E. Cristiani, Modelli di agricoltura ,sostenibile” con particolare attenzione al settore vitivinicolo, w: R. Budzinowski (red.), XV World Congress of Agricultural Law. Contemporary Challenges of Agricultural Law: Among Globalization, Regionalization and Locality, Poznań 2018, s. 361-367; R. Budzinowski, A. Suchoń, Relacja gospodarstwa rolnego i przedsiębiorstwa rolnego $w$ świetle publicznych mechanizmów ich wspierania, w: P. Litwiniuk (red.), Prawne mechanizmy wspierania i ochrony rolnictwa rodzinnego w Polsce i innych państwach Unii Europejskiej, Warszawa 2015, s. 323-334; M.A. Król, Ekologizacja Wspólnej Polityki Rolnej, „Zeszyty Naukowe SGGW w Warszawie. Polityki Europejskie, Finanse i Marketing” 2013, nr 10(59), s. 402-421; K. Leśkiewicz, Bezpieczeństwo żywnościowe i bezpieczeństwo żywności-aspekty prawne, „Przegląd Prawa Rolnego" 2012, nr 1(10), s. 179-197. 
tów „dostępu do żywności”. Jak wskazuje Tomasz Srogosz, wspomniane kategorie można potraktować łącznie, także w kontekście sytuacji porównywalnych do trwającej pandemii ${ }^{10}$.

Za opracowaniem zagadnienia zrównoważonych systemów żywnościowych przemawiają względy społeczno-gospodarcze oraz poznawcze. Jeśli chodzi o względy społeczno-gospodarcze, to należy zwrócić uwagę, że z jednej strony od lat utrzymuje się wysoki wskaźnik procentowy niedożywienia (głodu), z drugiej zaś - widoczne są skutki nadmiaru żywności w niektórych częściach świata ${ }^{11}$. Jednocześnie wobec wzrostu liczby ludności i globalnej konsumpcji mięsa o $82 \%$ do 2050 r. należy się spodziewać pogłębienia tych negatywnych zjawisk ${ }^{12}$. Niezwykle trudne jest osiągnięcie stanu bezpieczeństwa żywnościowego, zważywszy, że rolnictwo odpowiada za 10,3\% emisji gazów cieplarnianych w UE, z czego prawie 70\% pochodzi z sektora chowu zwierząt, co gorsza, wykorzystuje aż $68 \%$ powierzchni gruntów rolnych do produkcji zwierzęcej ${ }^{13}$.

Jak wskazywał Europejski Komitet Ekonomiczno-Społeczny w 2018 r., ramy prawne polityki UE nie są dostosowane do przejścia na bardziej zrównoważone systemy żywnościowe mające zapewnić skuteczne wdrożenie celów ONZ w zakresie zrównoważonego rozwoju, a także realizację prawa do pożywienia oraz innych praw człowieka. Podkreślał również, że kompleksowa polityka żywnościowa powinna uzupełniać przekształconą WPR, nie może natomiast jej zastępować ${ }^{14}$. Nie ulega jednak wątpliwości, że zrównoważone systemy żywnościowe obejmujące cały łańcuch żywności będą w dużym stopniu zależeć od sektora rolnictwa i WPR. Jedynie spójność zastosowanych narzędzi realizacji wymienionych polityk może przynieść zakładane efekty.

Jeśli chodzi o względy poznawcze, to analiza planowanego podejścia w nowej perspektywie finansowej w latach 2021-2027 pozwoli poznać nowe rozwiązania przeobrażonej WPR i zestawić je z założeniami zrównoważonych systemów żywnościowych formułowanych w polityce żywnościowej ujętych w strategii „Od pola do stołu”. Według zapowiedzi nowa WPR

10 T. Srogosz, Systemy żywnościowe...

11 WHO, Global Health Observatory, 2015, https:/www.who.int/health-topics/obesity\# tab=tab_1 [dostęp: 20.09.2020].

12 Ibidem.

${ }^{13}$ Komunikat Komisji do Parlamentu Europejskiego, Rady, Europejskiego Komitetu Ekonomiczno-Społecznego i Komitetu Regionów, Strategia „Od pola do stołu” na rzecz sprawiedliwego, zdrowego i przyjaznego dla środowiska systemu żywnościowego, COM/2020/381 final, https:// www.europarl.europa.eu/news/pl/headlines/society/20200519STO79425/stworzenie-zrownowazonego-systemu-zywnosciowego-strategia-ue [dostęp: 15.09.2020].

${ }^{14}$ Opinia Europejskiego Komitetu Ekonomiczno-Społecznego w sprawie możliwego przekształcenia Wspólnej Polityki Rolnej (Dz. Urz. UE C 288 z 31.08.2017). 
będzie nowoczesna i podporządkowana realizacji Europejskiego Zielonego Ładu $^{15}$, w którym wskazano, że „europejska żywność powinna również stać się światowym standardem zrównoważoności”. Produkcja żywności nadal powoduje zanieczyszczenie powietrza, wody i gleby, przyczynia się do utraty różnorodności biologicznej i zmiany klimatu oraz pochłania ogromną ilość zasobów naturalnych, a jednocześnie duża część wyprodukowanej żywności jest marnowana. Wnioski ustawodawcze Komisji w obszarze WPR na lata 2021-2027 przewidują, że co najmniej 40\% budżetu WPR i co najmniej 30\% budżetu Europejskiego Funduszu Morskiego i Rybackiego zasili działania na rzecz walki ze zmianą klimatu.

Artykuł stanowi zatem próbę wstępnego ustalenia, czy założenia WPR na lata 2021-2027 można uznać za sprzyjające celom zrównoważonych systemów żywnościowych przyjętym w strategii „Od pola do stołu”. Skala i różnorodność problemów, których dotyczy opracowanie, nie pozwala na wyczerpujące omówienie wszystkich wątków, dlatego zasygnalizowane zostaną tylko niektóre z nich.

Już w 2016 r. Europejski Komitet Ekonomiczno-Społeczny wyraził opinię na temat przejścia na „bardziej zrównoważone systemy żywnościowe"16. Wśród najważniejszych obszarów działań wskazano: promowanie produkcji żywności bardziej zasobooszczędnej i odpornej na zmianę klimatu oraz utrzymanie modelu rodzinnych gospodarstw rolnych w Europie; założenia gospodarki o zamkniętym obiegu; wzmocnienie powiązania między systemami żywnościowymi a strategiami dotyczącymi zmiany klimatu; promowanie zdrowszego odżywiania się ludzi; zwalczanie chorób zwierząt i roślin, które mają niekorzystny wpływ na systemy żywnościowe (np. afrykański pomór świń) $)^{17}$.

Zrównoważone systemy żywnościowe zostały więc objęte planami przyszłej polityki żywnościowej. Wskazano, że polityka żywnościowa dostosowana do XXI wieku powinna uwzględniać szereg kryteriów, w tym: jakość żywności, środowisko, wartości społeczne i kulturowe; solidne podstawy gospodarki, uzasadnione, konkurencyjne ceny i dobre sprawowanie rządów ${ }^{18}$.

${ }^{15}$ Komunikat Komisji Europejskiej, Europejski Zielony Ład, Bruksela 11 grudnia 2019 r. (COM 2019 (640) final), https://eur-lex.europa.eu/legal-content/PL/TXT/HTML/?uri=CELEX:52019DC0640\& from=EN [dostęp: 20.09.2020].

16 Opinia Europejskiego Komitetu Ekonomiczno-Społecznego w sprawie bardziej zrównoważonych systemów żywnościowych (opinia rozpoznawcza), 2016/C 303/08 (Dz. Urz. UE C 303/64 z 19.08.2016).

17 Ibidem.

${ }_{18}$ Opinia Europejskiego Komitetu Ekonomiczno-Społecznego, Wkład społeczeństwa obywatelskiego w rozwój kompleksowej polityki żywnościowej w UE (opinia z inicjatywy własnej), 2018/C 129/04 (Dz. Urz. UE C 129/18 z 11.04.2018). 
2. Zrównoważone systemy żywnościowe stały się elementem Europejskiego Zielonego Ładu ${ }^{19}$, który wpisuje się w realizację celów zrównoważonego rozwoju $\mathrm{ONZ}^{20}$. Co ciekawe, wedle rezolucji ONZ - jak wskazuje T. Srogosz - „nie można mówić o jednym, ale o wielu zrównoważonych systemach żywnościowych (sustainable food production systems), powiązanych z ekosystemami (that help maintain ecosystems)" ${ }^{21}$. A zatem nie można mówić np. o systemie europejskim, co najwyżej o systemach krajowych i lokalnych, choć i z tym poglądem można polemizować.

Aby ustalić znaczenie wyrażenia ,zrównoważone systemy żywnościowe", należy zweryfikować sens jego poszczególnych słów, a następnie odnieść się do dokumentów, w których ono występuje. I tak, słowo „zrównoważony” oznacza „spokojny, opanowany; też: świadczący o takich cechach”22; ,„system” oznacza „1. «układ elementów mający określoną strukturę i stanowiący logicznie uporządkowaną całość» 2. «zespół wielu urządzeń, dróg, przewodów itp., funkcjonujących jako całość»" "23, zaś ,,żywnościowy" może oznaczać wszystko, co ma związek z żywnością. Pojęcie żywności definiuje zaś rozporządzenie $\mathrm{nr}$ 178/2002 24 .

Ponieważ żywnością mogą być w szczególności produkty rolne, należy mieć na uwadze to, że według art. 38 ust. 1 TFUE ${ }^{25}$ UE określa i realizuje Wspólną Politykę Rolną i Wspólną Politykę Rybołówstwa. Rynek wewnętrzny obejmuje także rolnictwo, rybołówstwo i handel produktami rolnymi. Przez produkty rolne należy rozumieć płody ziemi, produkty pochodzące $\mathrm{z}$ hodowli i rybołówstwa, jak również produkty pierwszego przetworzenia, które pozostają w bezpośrednim związku z tymi produktami (art. 38 ust. 1 TFUE).

${ }_{19}$ Rezolucja Parlamentu Europejskiego z 15 stycznia 2020 r. w sprawie Europejskiego Zielonego Ładu (2019/2956(RSP)).

${ }^{20}$ Rezolucja przyjęta przez Zgromadzenie Ogólne 25 września 2015 r. [bez odniesienia do Komitetu Głównego (A/70/L.1)] 70/1. Przekształcamy nasz świat: Agenda na rzecz zrównoważonego rozwoju 2030, http://www.unic.un.org.pl/files/164/Agenda\%202030_pl_2016_ostateczna. pdf [dostęp: 29.08.2020].

${ }_{21}$ T. Srogosz, Systemy żywnościowe...

22 Stownik Języka Polskiego PWN, https://sjp.pwn.pl/szukaj/zrównoważony\%20.html [dostęp: 15.09.2020].

${ }^{23}$ Stownik Języka Polskiego PWN, https://sjp.pwn.pl/szukaj/system.html [dostęp: 15.09.2020].

${ }^{24}$ Rozporządzenie (WE) nr 178/2002 Parlamentu Europejskiego i Rady z 28 stycznia 2002 r. ustanawiającego ogólne zasady i wymagania prawa żywnościowego, powołującego Europejski Urząd do Spraw Bezpieczeństwa Żywności oraz ustanawiającego procedury w sprawie bezpieczeństwa żywności (Dz. Urz. WE L 31 z 1.02.2002, s. 1; Dz. Urz. UE polskie wydanie specjalne, rozdz. 15 , t. 6 , s. 463$)$.

${ }^{25}$ Traktat o funkcjonowaniu Unii Europejskiej, wersja skonsolidowana (Dz. Urz. UE C 326 z 26.10.2012, s. 1-390). 
Jednocześnie produkty, których dotyczą art. 39-44 TFUE, są wymienione na liście stanowiącej załącznik I.

Dokonane ustalenia terminologiczne pozwalają stwierdzić, że zrównoważone systemy żywnościowe mogą oznaczać układ lub układy logicznie powiązanych elementów w sferze wytwarzania, przetwarzania produktów rolnych lub żywności, o opanowanym (zrównoważonym) charakterze. Cechę zrównoważenia można przy tym odnosić do wszystkich aspektów produkcji, wykorzystania zasobów, technik i metod produkcji, stosowanych substancji, wytwarzania i gospodarki odpadami, emisji gazów do atmosfery czy konsumpcji. Efektem takiej kompozycji powinien być produkt - żywność, pozwalający zaspokoić potrzeby związane z food security.

3. Celem strategii „Od pola do stołu” jest budowa zrównoważonego systemu żywnościowego zapewniającego bezpieczeństwo żywnościowe i chroniącego ludzi oraz środowisko naturalne. Ambicją Komisji jest budowanie łańcucha żywnościowego, który działa na rzecz konsumentów, producentów, klimatu i środowiska. Działania podporządkowane temu celowi obejmują zmniejszenie śladu środowiskowego i klimatycznego unijnego systemu żywnościowego oraz wzmocnienie jego odporności, zapewnienie bezpieczeństwa żywnościowego i dążenie do bycia liderem globalnej transformacji w kierunku konkurencyjnej zrównoważoności od pola od stołu. Wpisują się one w łańcuch żywnościowy, który obejmuje produkcję, transport, dystrybucję, marketing i konsumpcję żywności neutralne lub pozytywne dla środowiska, a to dzięki ochronie i odbudowie zasobów, zdrowia roślin i zwierząt oraz dobrostanu zwierząt i różnorodności biologicznej. Wśród priorytetowych obszarów znalazło się: zapewnienie zrównoważonej produkcji żywności i bezpieczeństwa żywnościowego; pobudzanie zrównoważonych praktyk w zakresie przetwórstwa spożywczego, sprzedaży hurtowej i detalicznej, hotelarstwa i gastronomii, promowanie zrównoważonej konsumpcji żywności oraz ułatwienie przejścia na zdrową i zrównoważoną dietę, a także ograniczenie strat i marnotrawienia żywności oraz zwalczanie fałszowania żywności w łańcuchu dostaw żywności. Każde z tych wyzwań wymaga uszczegółowienia i odniesienia do kolejnych elementów łańcucha żywnościowego. Akcent położono tu nie tylko na produkcję żywności w ramach nowej WPR, bardziej ekologicznej i prośrodowiskowej, ale także na otoczenie konsumpcji i żywienie czy gospodarkę żywnościową. Komisja zobowiązała się do przedstawienia przed końcem 2023 r. propozycji ustawodawczych „ram zrównoważonego systemu żywnościowego”. Zarysowany kształt przyszłego „modelu” zrównoważonych systemów żywnościowych będzie wymagać solidnych podstaw 
prawnych służących przeorientowaniu rozwiązań WPT w kierunku ścisłego powiązania jej z instrumentami ochrony klimatu. Unijne rolnictwo objęte polityką rolną będzie bowiem stanowiło filar systemu żywnościowego.

4. Biorąc pod uwagę cele WPR zdefiniowane w art. 39 ust. 1 TFUE, można stwierdzić, że strategia zrównoważonych systemów żywnościowych Komisji Europejskiej odpowiada większości z nich. Niektóre cele są nawet zbieżne pod względem językowym z projektowanymi założeniami zrównoważonego systemu żywnościowego, np. zapewnienie odpowiedniego poziomu życia ludności wiejskiej, zwłaszcza przez podniesienie indywidualnego dochodu osób pracujących w rolnictwie, a także zagwarantowanie bezpieczeństwa dostaw i rozsądnych cen w dostawach dla konsumentów. Brakuje w nich odwołania, czy choćby zaakcentowania, potrzeby ochrony środowiska, w tym jego zasobów i klimatu. W TFUE mowa jest jedynie o optymalnym wykorzystaniu czynników produkcji, do których można co prawda zakwalifikować grunty rolne, jednak wydaje się to niewystarczające. Wymogi ochrony klimatu mają natomiast podstawy w innych przepisach TFUE, regulacjach polityki klimatycznej i aktach międzynarodowych ${ }^{26}$.

Nie jest obecnie możliwe dokonanie ostatecznych ustaleń, czy konkretne rozwiązania WPR w przyjętych ramach prawnych będą adekwatne do założeń strategii „Od pola do stołu” w zakresie budowania zrównoważonego systemu żywnościowego. Oczywiste jest bowiem to, że ocena efektów tej strategii będzie możliwa dopiero po pewnym czasie od jej wdrożenia.

Należy jednak zgodzić się z Komisją UE, że zapewnienie odpowiedniego wsparcia, a tym samym dochodów gospodarstwom rolnym stanowi warunek bezpieczeństwa żywnościowego, realizacji ambitnych celów dotyczących środowiska i klimatu oraz witalności obszarów wiejskich w przyszłości. Aby WPR sprzyjała zrównoważonemu rozwojowi rolnictwa, produkcji żywności oraz obszarów wiejskich, musi mieć cele zorientowane na rentowność i dochody gospodarstw rolnych, bardziej skuteczną realizację polityki w zakresie ochrony środowiska i klimatu, a także na zrównoważony rozwój obszarów wiejskich.

Wyznaczenie kierunku ochrony środowiska i klimatu w ramach WPR zasługuje na aprobatę, zwłaszcza że w perspektywie finansowej 20132020 działania te były bardzo ograniczone. Rolnictwo musi zostać podporządkowane realizacji polityki klimatycznej, jednak przy znaczącym wsparciu gospodarstw rodzinnych, których działalność może zapewnić

${ }^{26}$ M. Górski, Konwencja klimatyczna, w: M. Górski (red.), Prawo ochrony środowiska, Warszawa 2018, s. 290 i nn. 
wytwarzanie żywności w sposób zrównoważony, z poszanowaniem zasobów, ograniczający szkodliwą dla klimatu emisję gazów cieplarnianych i pozwalający wytwarzać żywność bezpieczną i dobrej jakości. Zresztą już w komunikacie Komisji UE z 29 listopada 2017 r. pt. „Przyszłość rolnictwa i produkcji żywności” ${ }^{27}$ wskazano, że „WPR musi nadać impuls do przejścia na bardziej zrównoważone rolnictwo".

Zgodnie z uzasadnieniem projektu rezolucji ustawodawczej Parlamentu Europejskiego w sprawie wniosku dotyczącego rozporządzenia Parlamentu Europejskiego i Rady ustanawiającego przepisy dotyczące wsparcia na podstawie planów strategicznych sporządzanych przez państwa członkowskie w ramach Wspólnej Polityki Rolnej (planów strategicznych WPR) i finansowanych z Europejskiego Funduszu Rolniczego Gwarancji (EFRG) i z Europejskiego Funduszu Rolnego na rzecz Rozwoju Obszarów Wiejskich (EFRROW) oraz uchylającego rozporządzenie Parlamentu Europejskiego i Rady (UE) nr 1305/2013 i rozporządzenie Parlamentu Europejskiego i Rady (UE) nr 1307/2013) $)^{28}$ należy uznać, że proponowany kierunek radykalnej zmiany paradygmatu WPR daje szanse na to, aby sprostać wyzwaniom i założeniom budowy zrównoważonych systemów żywnościowych. Według tego dokumentu w propozycji reformy WPR przedstawionej przez Komisję Europejską planuje się przejście od systemu o charakterze normatywnym, opartego na normach kwalifikowalności, do systemu opartego na konkretnych rezultatach, z naciskiem na środowisko, w którym wzrasta rola państw członkowskich działających na zasadzie pomocniczości. Nowy model WPR ma wynikać $\mathrm{z}$ połączenia $\mathrm{w}$ jednym akcie prawnym (rozporządzeniu) rozwiązań dotyczących pierwszego i drugiego filara, a także z włączenia do niego znacznej części zasad wspólnej organizacji rynku produktów rolnych, w kontekście nowych krajowych planów strategicznych. Rola Komisji UE ma polegać na monitorowaniu poziomu realizacji celów wyznaczonych przez państwa członkowskie na podstawie wspólnych celów szczegółowych. Najważniejsze założenia reformy to redystrybucja pomocy WPR, modernizacja, innowacje, a przede wszystkim rolnictwo bardziej zaangażowane na rzecz środowiska ${ }^{29}$.

W stanowisku objętym rezolucją można odnotować podejście związane ze zrównoważoną gospodarką rolną, szanującą zasoby, mającą przyczyniać

27 Komunikat w sprawie Wspólnej Polityki Rolnej po 2020 r., Przyszłość produkcji żywności i rolnictwa, Bruksela, 29 listopada 2017 r., https://ec.europa.eu/commission/presscorner/detail/pl/ MEMO_17_4842 [dostęp: 20.09.2020].

${ }^{28} \overline{\mathrm{COM}}(2018) 0392-\mathrm{C} 8-0248 / 2018-2018 / 0216(\mathrm{COD})$, https://www.europarl.europa.eu/doceo/document/A-8-2019-0200_PL.html\#title2 [dostęp: 23.10.2020].

${ }^{29}$ Ibidem. 
się do łagodzenia zmiany klimatu, a także wspieranie wykorzystania zrównoważonej energii, jak również zapewnienie bezpieczeństwa żywnościowego w przyszłości przez ograniczenie emisji gazów cieplarnianych w sektorze rolno-spożywczym, w tym sekwestrację dwutlenku węgla w glebie i ochronę lasów. Wydaje się jednak, że budowanie zrównoważonych systemów żywnościowych powinno być bardziej skonkretyzowane $\mathrm{i}$ jaśniej sformułowane w przyszłych aktach prawnych dotyczących WPR, aby nie pozostało tylko oczekiwaniem w sferze polityki.

5. Mając na uwadze przyszłe ramy prawne i działania ujęte w projektach przywołanych dokumentów, można stwierdzić, że skoro wzrośnie rola państw członkowskich w realizacji strategicznych celów WPR, jak i zrównoważonych systemów żywnościowych, to większego znaczenia nabierze prawodawstwo krajowe w tej kwestii. Jak przyjmuje się w literaturze, pojęcie bezpieczeństwa w świetle art. 5 Konstytucji RP należy rozumieć szeroko - ,jako stan dający poczucie pewności i stabilności oraz gwarancji jego ochrony" 30 . Wynika to z obowiązku władz publicznych prowadzenia polityki zapewniającej bezpieczeństwo ekologiczne współczesnemu i przyszłym pokoleniom (art. 74 ust. 1 Konstytucji RP) oraz ochrony środowiska (art. 74 ust. 2). Zasada zrównoważonego rozwoju pełni więc rolę dyrektywy wykładni (podobnie jak zasady współżycia społecznego czy społeczno-gospodarcze przeznaczenie w prawie cywilnym), co znajduje wyraz w orzecznictwie sądów administracyjnych ${ }^{31}$. W polskim porządku prawnym obowiązują bowiem przepisy Konstytucji RP umożliwiające pełną realizację celów przyszłej WPR zorientowanej na ochronę środowiska oraz strategii „Od pola do stołu”. Jeśli chodzi o możliwość wykonania wskazanych kierunków polityki unijnej, to wiele będzie zależało od kształtu uregulowań na poziomie krajowym i podejścia poszczególnych państw do ochrony klimatu.

6. Podsumowując przedstawione rozważania, można sformułować kilka wniosków. Założenia zrównoważonych systemów żywnościowych ujęte w strategii „Od pola do stołu” korespondują z niektórymi celami WPR zawartymi w TFUE, a nawet świetnie je wypełniają. Można się jednak obawiać, czy w aktach prawa pochodnego, których celem będzie wdrożenie szczegółowych rozwiązań przyszłej WPR, nie dojdzie do zbytniej relatywizacji standardu ochrony środowiska na rzecz wsparcia dochodów

${ }^{30}$ L. Bosek, Komentarz do art. 5, w: M. Safjan, L. Bosek (red.), Konstytucja RP, t. I: Komentarz do art. 1-86, Warszawa 2016.

${ }^{31}$ Ibidem. 
rolników. Proponowany kierunek zmiany paradygmatu WPR, w sposób ujęty we wniosku dotyczącym rozporządzenia Parlamentu Europejskiego i Rady ustanawiającego przepisy dotyczące wsparcia na podstawie planów strategicznych sporządzanych przez państwa członkowskie w ramach Wspólnej Polityki Rolnej (planów strategicznych WPR) i finansowanych z Europejskiego Funduszu Rolniczego Gwarancji (EFRG) i z Europejskiego Funduszu Rolnego na rzecz Rozwoju Obszarów Wiejskich (EFRROW) oraz uchylającego rozporządzenie Parlamentu Europejskiego i Rady (UE) nr 1305/2013 i rozporządzenie Parlamentu Europejskiego i Rady (UE) nr 1307/2013, stwarza szanse sprostania wyzwaniom i założeniom budowy zrównoważonych systemów żywnościowych. Istotne będzie także podejście krajów członkowskich do realizacji ambitnych celów polityki klimatycznej w ramach Europejskiego Zielonego Ładu.

Ostateczna ocena tego, czy nowa WPR przyniesie efekty w obszarze budowania zrównoważonych systemów żywnościowych, będzie wymagać odwołania się nie tylko do przyszłej regulacji prawnej, odpowiadającej kolejnemu okresowi finansowania, ale także do skutków jej stosowania w przyszłości. Można mieć wątpliwości, czy radykalna zmiana kierunku WPR i konieczność realizacji celów zrównoważonego rozwoju nie doprowadzi do konfrontacji i konkurencji instrumentów wsparcia dochodów rolniczych $\mathrm{z}$ instrumentami ochrony środowiska, w tym klimatu, kosztem tych ostatnich.

\title{
SUSTAINABLE FOOD SYSTEMS IN THE CONTEXT OF THE COMMON AGRICULTURAL POLICY REFORM - LEGAL ASPECTS
}

\author{
Summary
}

The focus of this article was at a preliminary assessment of whether the proposed assumptions of the Common Agricultural Policy for 2021-2027 could be considered conducive to the objectives of sustainable food systems included in the European Commission's "From farm to fork" strategy. In the author's opinion, the assumptions of sustainable food systems contained in this document correspond to some objectives of the Common Agricultural Policy included in the Treaty on the Functioning of the European Union. The final assessment whether the new common agricultural policy will bring effects from the point of view of building sustainable food systems requires making a reference not only to the future legal regulation which will apply in the next financing perspective, but also to the effects of its application. A radical change in the directions of the Common Agricultural Policy and implementation of sustainable development objectives may lead to a confrontation and competition of agricultural income support instruments with those for environmental protection including climate protection, at the expense of the latter. 


\title{
SISTEMI ALIMENTARI SOSTENIBILI NEL CONTESTO DELLA RIFORMA DELLA POLITICA AGRICOLA COMUNE - ASPETTI GIURIDICI
}

\begin{abstract}
Riassunto
L'articolo di propone di formulare un giudizio preliminare riguardo alle proposte presentate per la PAC 2021-2027, in particolare riguardo al loro carattere a favore degli obiettivi stabiliti per i sistemi alimentari sostenibili, inclusi nella strategia della Commissione europea "Dal campo alla tavola". Secondo l'autrice, le ipotesi prestabilite per i sistemi alimentari sostenibili, e incluse nel documento discusso, corrispondono ad alcuni degli obiettivi della politica agricola comune contenuti nel Trattato sul funzionamento dell'Unione europea. Tuttavia, per esprimere un giudizio finale, ossia per rispondere alla domanda se la nuova politica agricola comune avrà effetti per la costruzione di sistemi alimentari sostenibili, è necessario riferirsi non solo ad una regolazione futura, in vigore dalla prossima prospettiva di finanziamento, ma anche agli effetti che la sua applicazione porterà a produrre. Un cambiamento radicale prodottosi negli orientamenti della politica agricola comune, nonché l'attuazione degli obiettivi di sviluppo sostenibile possono portare a far nascere una situazione di confronto e concorrenza tra strumenti di sostegno al reddito agricolo e quelli di protezione ambientale, compresa la tutela del clima, a scapito di questi ultimi.
\end{abstract}

